\title{
Poljsko javno mišljenje o nastanku Kraljevstva Srba, Hrvata i Slovenaca 1918.
}

\author{
MIROSŁAW DYMARSKI \\ Uniwersytet Wrocławski, Instytut Politologii \\ Wrocław, Poljska \\ miroslaw.dymarski@uwr.edu.pl
}

Poljska javnost bila je zainteresirana za zbivanja među Južnim Slavenima. Nastanak Kraljevstva Srba, Hrvata i Slovenaca poljski tisak tretirao je kao prirodno pravo malih naroda na samoodređenje. Sa simpatijama su promatrana nastojanja Slovenaca, Hrvata i Srba. Nije to, naravno, bila tema prvih stranica novina budući da se u tom trenutku obnavljala i sama Poljska. No poljska je javnost bila upoznata s djelatnošću glavnih slovenskih, hrvatskih i srpskih političara, bili su joj poznati problemi njihove borbe s Talijanima oko granica, a izražavane su i bojazni o jedinstvu države katolika, pravoslavaca i muslimana. Nije favorizirana nijedna strana. Često su se koristili pojmovi Jugoslavija i Jugoslaveni, i to još i prije negoli je došlo do ujedinjenja Slovenaca, Hrvata i Srba.

Ključne riječi: Poljska; javno mišljenje; tisak; Prvi svjetski rat; Kraljevstvo Srba, Hrvata i Slovenaca

U Poljskoj se već dugo istražuju poljsko-jugoslavenski odnosi. U posljednje je vrijeme na inicijativu Sveučilišta u Bydgoszczu i Instituta za savremenu istoriju iz Beograda objavljena serija zbornika radova posvećenih različitim aspektima odnosa između Poljske i Kraljevstva Srba, Hrvata i Slovenaca (SHS) / Jugoslavije, odnosno poslijeratne Jugoslavije. ${ }^{1}$ No dosad nitko nije istraživao stav poljskoga javnog mišljenja prema nastanku Kraljevstva SHS 1918. godine. Je li pitanje stvaranja jugoslavenske države ujesen 1918. zanimalo poljsku javnost? Je li poljsko društvo uopće znalo išta o tome? Kakav je bio odnos prema nastojanjima Južnih Slavena 1918. ako je za Poljake u to vrijeme bila najvažnija obnova vlastite države nakon 123 godine pod stranom vlašću? Ocjenu stanovišta poljskoga javnog mišljenja prema Jugoslaviji koja se rađala omogućilo je

1 PAVLOVIĆ, ZAĆMIŃSKI, Polska i Jugosławia $w$ stosunkach międzynarodowych; PAVLOVIĆ, ZAĆMIŃSKI, BONDŽIĆ, Jugoslovensko-poljski odnosi u XX veku; PAVLOVIĆ, WAWRYSZUK, ZAĆMIŃSKI, Polska i Jugosławia w XX wieku; PAVLOVIĆ, ZAĆMIŃSKI, STAMBOLIJA, Jugoslavija i Poljska; DIMITRIJEVIĆ, WAWRYSZUK, ZAĆMIŃSKI, $W$ kręgu dyplomacji i polityki. 
istraživanje nekoliko vodećih listova koji su izlazili u poljskim zemljama na prijelazu 1918./1919. godine.

Rat od 1914. do 1918., kao prvi masovni rat, doveo je do tragedije mnogih naroda u Europi, do milijuna poginulih, velike ekonomske štete, gladi i dr. Odraz toga, među ostalim, bilo je i stanje poljskoga novinstva na prijelazu 1918./1919. godine. Zbog siromaštva, ratne cenzure i nedostatka papira broj novina koje su se pojavljivale posljednjih mjeseci Prvoga svjetskog rata i prvih mjeseci mira nije bio velik. Valja imati na umu da u Poljskoj, koja je tada bila podijeljena među tri države (Njemačka, Austro-Ugarska i Rusija), nije bilo općepoljskoga novinstva. Svaka od objavljenih publikacija predstavljala je stav neke lokalne zajednice: Varšave, Krakova, Lavova, Poznańa, Bydgoszcza itd. $\mathrm{U}$ vezi s ratnim djelovanjima poljske novine nisu imale svoje izvjestitelje $\mathrm{u}$ inozemstvu i najčešće su komentirale novinske vijesti. Nije bilo mnogo novina publicističkoga tipa jer je elita u to vrijeme bila preuska. Dominirali su informativni dnevnici i stranački tisak, što je bila prepreka posvećivanju većega prostora općim europskim i svjetskim temama.

Poljsko se javno mišljenje usprkos tim ograničenjima živo zanimalo za događaje iz života Južnih Slavena. Dosta je rano u poljskom novinstvu za to područje prihvaćen naziv Jugoslavija. Publicistika svih političkih pravaca i informativni tisak pratili su državotvorne težnje Južnih Slavena. Čak je i socijalističko novinstvo, koje je u to vrijeme bilo koncentrirano na društveni program Poljske i Europe, objavljivalo kratke vijesti iz političkoga života nove zemlje na slavenskom jugu².

Članak je utemeljen na glavnim novinama koje tvore javno mišljenje i predstavljaju pojedine regije podijeljene Poljske. Nakon izbijanja Prvoga svjetskog rata mnoštvo je poljskih novina i časopisa prestalo izlaziti, a preostali su se pojavljivali povremeno. Vrlo utjecajan dnevnik bio je Ilustrowany Kurier Codzienny (1910. - 1939.), koji je izlazio u Krakovu. Bile su to najveće poljske informativne novine, s dopisnicima u svim dijelovima Europe i Sjedinjenim Američkim Državama. Tijekom rata izlazile su u nakladi od oko 50 tisuća primjeraka, no krug njihovih čitatelja bio je mnogo veći. Novine su raspačavane među poljskim vojnicima u austrougarskoj vojsci. Izdavač im je bio najveći novinski koncern u zemlji (izdavao je i niz specijalističkih izdanja) ${ }^{3}$. Iz Krakova je bio i Czas, koji je izlazio od 1848. do 1934. i spadao među najvažnije poljske novine, često citirane i u inozemstvu. Predstavljao je konzervativne i znanstvene krugove Krakova. Naklada mu je dosezala 6-8 tisuća primjeraka (ponekad i 10 tisuća), a izlazio je dva puta dnevno ${ }^{4}$. U Varšavi je najvažniji dnevnik bila Gazeta Warszawska, koja je s prekidima izlazila od 1774. godine. No u srpnju 1915., nakon ulaska njemačke vojske u Varšavu, prestala je izla-

2 „Koalicja wobec Słowian”, Naprzód (Krakov), br. 124, 12. 6. 1918. U novinama Poljske socijalističke partije 17. prosinca 1918. pisano je o formiranju prvoga kabineta Kraljevstva SHS. Naprzód, br. 282, 17. 12. 1918.

BAŃDO, „Dzieje koncernu 'Ilustrowany Kurier Codzienny’ 1910-1939”, 601.

JAROWIECKI, „Prasa w Krakowie”, 35. 
ziti, pa nije uzeta u obzir u ovoj analizi. Varšavu predstavljaju Monitor Polski, službeni organ autonomne poljske vlade u Poljskom kraljevstvu (prvi je broj izašao 6. veljače 1918.), koji je imao i publicistički dio, i Kurier Warszawski (1821. - 1939.), časopis povezan s kršćansko-nacionalnim pokretom sa znatnim društvenim utjecajem. Njegova je naklada 1914. iznosila oko 50 tisuća primjeraka ${ }^{5}$. Valja naglasiti da je od časa kada je Varšava dospjela u njemačke ruke mogućnost izlaženja poljskih novina bila izrazito ograničena.

Dziennik Poznański (1859. - 1939.) utemeljio je u Poznańu poljski industrijalac Hipolit Cegielski. Predstavljao je liberalne nacionalne tendencije, a potom je postao konzervativni list. Izlazio je u nakladi od oko 10 tisuća primjeraka. List Naprzód bio je glasilo socijalista, a izlazio je od 1892. do 1948 . Godine 1913. naklada mu je bila 6 tisuća primjeraka.

Svi ti listovi objavljivali su informacije i komentare posvećene pitanjima Južnih Slavena s različitim intenzitetom, uglavnom dva-tri puta tjedno. Dziennik Poznański objavljivao ih je u stalnoj rubrici „Slavenska pitanja”. Naravno, u listopadu 1918. informacije o situaciji među Hrvatima, Slovencima i Srbima objavljivane su gotovo svakodnevno.

Članak obuhvaća razdoblje od 13. ožujka 1918., kad se u listu Monitor Polski pojavio prvi tekst o temi budućnosti Južnih Slavena, do 21. lipnja 1919., kad je u tjedniku Świat objavljen ilustrirani tekst kratko naslovljen „SHS”, u kojemu se opisuje novo kraljevstvo. Poljsko javno mišljenje nije bilo iznenađeno događajima ujesen 1918. i raspadom Austro-Ugarske.

Važno mjesto u razumijevanju težnji Južnih Slavena za ujedinjenjem imala je ideja ujedinjenja poljske zemlje, koja je 123 godine bila podijeljena između Njemačke, Rusije i Austrije, u jednu poljsku državu, što je bila ideja vodilja svih poljskih političkih pokreta. Na Balkanu su se ujedinjavale zemlje Južnih Slavena, a Poljska je nastajala ujedinjenjem svojih triju dijelova.

Prvi svjetski rat donio je velike promjene u život naroda srednje, istočne i južne Europe. Još je za vrijeme rata postalo jasno da dotadašnji politički poredak i dominacija velesila neće preživjeti svjetski konflikt. Deklaracija srpske vlade u emigraciji i Jugoslavenskoga odbora u Londonu, objavljena 1917. na Krfu, o ujedinjenju Južnih Slavena u jedno nezavisno kraljevstvo pod vlašću Karađorđevića bila je nagovještaj velikih promjena na jugu Europe. Dokument je govorio o troimenome narodu ${ }^{6}$ Slovenaca, Hrvata i Srba. Godine 1917. Antanta je priznala poljsku državu in spe, koju je predstavljao Poljski nacionalni komitet u Parizu kao politički predstavnik Poljaka. Trebalo bi ovdje dodati i Pitsburški sporazum Čeha i Slovaka iz svibnja 1918. i imat ćemo cjelokupnu sliku dinamičnih promjena u životu naroda srednje, istočne i jugoistočne Europe koje su trebale donijeti slobodu od dominacije Centralnih sila i Rusije.

Poljska javnost pomno je pratila događaje na Balkanu jer je osjećaj zajedničke sudbine s Hrvatima, Srbima, Crnogorcima i Slovencima doprinio da se s

5 GODLEWSKA, „Prasa warszawska w pierwszym roku I wojny światowej”, 246.

6 СТАНКОВИЋ, Сто говора Николе Пашића, 311. 
dobronamjernim interesom promatra i komentira njihova borba za ostvarenje nacionalnih ili zajedničkih ciljeva. Simpatija Poljaka na strani Južnih Slavena tim je prije razumljiva jer je njihova težnja bila slična poljskoj: osloboditi se austrougarske dominacije i stvoriti vlastitu državu.

Važan je bio i nedostatak bilo kakva konflikta teritorijalnoga karaktera Poljaka s Južnim Slavenima. Drugačija je situacija bila s Česima i Slovacima, gdje je susjedstvo istovremeno značilo rivalstvo (Tješinska Šleska, Spiż), pa čak i konflikt. U odnosu prema Južnim Slavenima postojalo je razumijevanje i simpatije za njihove težnje. Pritom bi trebalo istaknuti da u poljskom javnom mišljenju nije postojalo favoriziranje jednoga naroda - s poštovanjem i simpatijom Poljaci su se odnosili prema Srbima, Hrvatima, Slovencima, Bosancima itd. kao narodima koji su stvarali dobrovoljnu zajednicu. U svim novinskim izvještajima koji su se odnosili na ideju ujedinjenja vidio se veliki entuzijazam s poljske strane, ponekad možda čak i veći nego kod samih Južnih Slavena. „Ne treba dodavati”, pisao je krakovski Czas, „da Poljaci mogu samo vatreno i iskreno željeti svojim južnim pobratimima da što je prije moguće dođu do međusobnoga sporazuma i stvore državnu organizaciju koja će ravnomjerno uzeti u obzir sve njihove plemenske posebnosti".?

Poljskom javnom mišljenju bliska je bila ideja ujedinjenja bratskih naroda, osobito zato što nije nosila nikakve asocijacije na rusku ideju panslavizma, nego je bila izraz autonomnih težnji Slavena. Monitor Polski pisao je u ožujku 1918. da među Slavenima više nema mjesta za „romantičnu hipnozu panslavizma” jer se sada radi o nacionalnim interesima ${ }^{8}$.

Osobit interes za pitanja Južnih Slavena pokazivao je tisak nekadašnje Galicije, poljskoga teritorija koji je do 1914. pripadao Austro-Ugarskoj (Krakov, Lavov). Najviše pozornosti južnoslavenskoj problematici posvećivali su Ilustrowany Kurier Codzienny i Czas. U tim novinama nalaze se vijesti i kratki komentari na temu Južnih Slavena. ${ }^{9}$ Ponekad su informacije o južnoslavenskom pitanju isticane velikim slovima ili podebljanim fontom da bi se naglasila važnost teksta za izdavače novina kao i za poljsko javno mišljenje uopće.

Moglo bi se reći da su i Južni Slaveni slali signale simpatije Poljacima. Ante Tresić Pavičić, zastupnik u Carevinskom vijeću, u svojem je govoru kritizirao Brestlitovski mirovni sporazum s boljševičkom Rusijom (18. ožujka 1918.), koji je vrijeđao interese Poljaka. Govorio je da „Poljaci neće više biti strpljivi kada se uspostavlja mir jednim rezom na njihovu živom tijelu. Dobro je da su Poljaci napokon naučili raspoznavati austrijsku zahvalnost"10.

\footnotetext{
„Belgrad czy Zagrzeb?”, Czas (Krakov), br. 506, 17. 11. 1918.

„Ukoliko južnoslavenski blok ili velikosrpski manifest s obzirom na svoje konkretne intencije [...] ima svoje političko pravo - utoliko će stvaranje principa koji se zove 'slavenska politika’ uvijek ulaziti u oblast fantastike i zabluda.” „Nastroje tzw. słowiańskie”, Monitor Polski (Varšava), br. 22, 13. 3. 1918.

9 Npr. izvještaj sa sjednica bečkoga parlamenta koji se tiče Južnih Slavena. „O południową Słowiańszczyznę", Czas, br. 222, 17. 5. 1918

10 Monitor Polski, br. 21, 12. 3. 1918.
} 
U komentarima koji se tiču situacije Južnih Slavena napravljene su i neke pogreške. Monitor Polski, službeno glasilo autonomne poljske vlade u Poljskom kraljevstvu (nekadašnjih poljskih oblasti koje su ulazile u sastav Ruskoga Carstva, a koje su od 1915. okupirali Nijemci i Austro-Ugarska), u ožujku 1918. pisao je o Krfskoj deklaraciji kao o „velikosrpskoj deklaraciji”. Posebno je karakteristično da su se prve informacije o situaciji Južnih Slavena pojavile baš na stranicama Monitora Polskog. I naziv Jugoslavija najprije se pojavljuje tamo i korišten je kao odrednica buduće države Južnih Slavena. Već u veljači 1918. Monitor Polski informirao je o tajnim pregovorima između Italije i zapadnih država koji su se ticali talijanskih teritorijalnih aspiracija na području Jadrana. Planovi su govorili o pripajanju Italiji cijele Dalmacije. „Ambiciozni planovi”, komentirala je redakcija Monitora Polskog. „Njihova 'realizacija' osigurala bi Italiji vlast na Jadranu i omogućila joj da postigne hegemoniju na istočnoj strani Sredozemnoga mora. Italija mašta o nasljedstvu Rima. Surova stvarnost ipak pokazuje nešto drugo. Fronta koja počinje već pod Venecijom čini se da raspršuje te beznadne snove." ${ }^{\prime 1}$ I krakovski Ilustrowany Kurier Codzienny u izvještajima od 4. prosinca 1918. pisao je s neodobravanjem da Talijani traže slavenska područja i teže talijanizaciji cijeloga Jadrana. To nije prihvaćano. ${ }^{12}$ Za poljsko javno mišljenje prvenstvo su imali interesi Slavena, a ne Italije, premda je potonja bila članica Antante kao i Poljska.

Treba priznati da je poljsko javno mišljenje bilo u dilemi kada se radilo o konfliktu zbog Jadrana i talijanskim aspiracijama prema Istri, Dalmaciji i Sloveniji. Talijani su odavno bili prihvaćeni kao prijateljski narod koji je podržavao Poljake u njihovoj borbi za slobodu. Italija je bila velesila koja je trebala odlučiti o budućnosti Poljske na konferenciji u Parizu. Poljska vlada, a osobito Ministarstvo vanjskih poslova, nije htjela izgubiti podršku vlasti u Rimu jer je, uz ostalo, o stavu talijanske vlade ovisila sudbina Poljske ${ }^{13}$. Ipak, talijanski zahtjevi u odnosu na slavenske zemlje bili su nerazumljivi. Generalno, nisu naišli na podršku u poljskom javnom mišljenju. Ni u jednom članku ili komentaru u poljskom tisku nije se pojavio nikakav glas koji bi stao u obranu talijanskih interesa na području Jadranskoga mora. Nikada nije razmatrana takva mogućnost. Naprotiv, kako je vrijeme prolazilo, tisak se jasno deklarirao da je na strani Južnih Slavena (Jugoslavena, kako je nekad pisano) jer su njihove težnje bile slične aspiracijama Poljaka. U jednom je članku napisano da „Poljaci i Južni Slaveni svoja pitanja mogu riješiti u međusobnom sporazumu jer u biti nema nikakvih suprotnosti među njima"14.

Tijekom cijeloga listopada 1918. u svim poljskim novinama pojavljivali su se tekstovi i komentari nakon proglašenja stvaranja Narodnoga vijeća Slo-

11 „Ambitne plany Włoch”, Monitor Polski, br. 7, 13. 2. 1918.

12 „Włosi żądają słowiańskich obszarów”, Ilustrowany Kurier Codzienny (Krakov), br. 241, 4. 12. 1918., 4. Jedan od dnevnih listova pisao je o ponašanju Talijana na slovenskom području: „Ponašaju se kao da su u osvojenoj zemlji." „Mobilizacja Słoweńców przeciwka Włochom”, Czas, br. 511, 22. 11. 1918.

13 STĘPNIAK, „Działalność dyplomacji polskiej w Królestwie SHS”, 51-52.

14 „Sprawy słowiańskie”, Dziennik Poznański (Poznań), br. 227, 3. 10. 1918. 
venaca, Hrvata i Srba u Austro-Ugarskoj ${ }^{15}$. Redakcija Monitora Polskog nije skrivala simpatije za Hrvate, Slovence i Srbe u njihovoj borbi za državnu samostalnost. Istovremeno su urednici znali za daljnje planove, ali - kao što je pisano - „o odnosu Narodnoga vijeća prema Srbiji ne može se još ništa konkretno reći. Vjerojatno će tu nastupiti temeljna promjena južnoslavenskoga i velikosrpskoga programa"16. Ponekad bi dio poljskoga javnog mišljenja nesvjesno podlegao srpskoj optici i koristio termin „velikosrpska zajednica” kao izraz težnji cijele zajednice Južnih Slavena tretiranih općenito, a ne kao izraz političkih ambicija koje je formulirao srpski premijer Nikola Pašić.

U to su vrijeme poljsko-južnoslavenski odnosi jačali. Monitor Polski objavio je 12. studenog 1918. vijest o telegramu koji je stigao iz Zagreba. Trebalo bi ju citirati u cijelosti: „U Poljsku likvidacijsku komisiju [Polska Komisja Likwidacyjna, privremeni organ poljske vlasti u Galiciji, op. M. D.] stigle su od predsjedništva slovensko-hrvatsko-srpskoga nacionalnog skupa depeše koje su bile upućene bivšem premijeru [Józefu] Świeżyńskom i bivšem ministru vanjskih poslova [Stanisławu] Głąbińskom u znak zahvalnosti za čestitke poljske vlasti poslane povodom konstituiranja slovensko-hrvatske države. Te depeše izražavaju i želje za jačanjem uzajamnih veza sa slobodnom Poljskom." ${ }^{\text {"17 }}$

Cijeli je tadašnji tisak (kao i političari) koristio dva termina: južnoslavenska država i Jugoslavija ${ }^{18}$. Termin Kraljevstvo SHS pojavio se kasnije, ne u prosincu 1918. nego tek 1919. godine. Naziv „južnoslavenska država” bio je privremeni pojam dok se još nije znalo kakav će sistemski i politički karakter imati, koji teritorij i narode i narodnosti obuhvaćati, ali se može reći da čak i maksimalni teritorijalni planovi Južnih Slavena nisu naišli na protivljenje u Poljskoj. Poljsko javno mišljenje davalo je carte blanche velikim teritorijalnim projektima Južnih Slavena. U jednom komentaru poluslužbenoga dnevnika Monitor Polski navedeno je koje bi zemlje mogle ući u državu Južnih Slavena: Hrvatska i Slavonija, Dalmacija, Rijeka, Međimurje, Banat, Bosna i Hercegovina, Istra, Kranjska, Gorica, južni dio Koruške, Trst, južna Ugarska. „Ako bi”, pisao je komentator Monitora Polskog, ,južnoslavensko pitanje bilo riješeno [...] pod parolom ujedinjavanja južnoslavenskih zemalja Austrije sa Srbi-

15 „Cesarz austriacki proklamuje państwo południowo-słowiańskie”, Naprzód, br. 226 11. 10. 1918.; „Państwo południowo-słowiańskie”, Kurier Warszawski (Varšava), br. 98, 29. 10. 1918.; „Południowo-słowiańska Rada Narodowa w Zagrzebiu”, Monitor Polski, br. 170, 8. 10. 1918., 3; „Federalizacja Austrii”, Monitor Polski, br. 178, 17. 10. 1918., 4; „Proklamacja Rady Narodowej Słowian Południowych", Ilustrowany Kurier Codzienny, br. 199, 23. 10. 1918. „Manifest południowych Słowian”, Czas, br. 471, 23. 10. 1918.; „Niezawisłość Jugosłowian”, Czas, br. 483, 30. 10. 1918.

16 „Rada Narodowa Słoweńców, Chorwatów i Serbów”, Monitor Polski, br. 196, 6. 11. 1918., 2.

17 „Słoweńsko-chorwacko-serbskie zgromadzenie do Polaków. PAT Kraków”, Monitor Polski, br. 201, 12. 11. 1918.

18 „Polacy a południowi Słowianie”, Czas, br. 499, 10. 11. 1918.; „Belgrad czy Zagrzeb?”, Czas, br. 506, 17. 11. 1918.; „Jugoslawia działa solidarnie”, Monitor Polski, br. 9, 13. 1. 1919. „Państwo południowosłowiańskie”, Kurier Poznański (Poznań), br. 98, 29. 10. 1918.; „Państwo południowosłowiańskie powstaje wśród krwawego zamętu", Ilustrowany Kurier Codzienny, br. 207, 31. 10. 1918. 
jom i Crnom Gorom [...] i [ta bi zemlja, op. M. D.] imala oko 11, eventualno 12 milijuna stanovnika, ne uzimajući u obzir teritorij na jugu poluotoka, koji će vjerojatno biti priključen Srbiji. Južnoslavenska država bit će sretna u takvim okolnostima, naime da strane nacionalnosti u njoj imaju samo zanemariv postotak, jer Talijani samo u južnim gradovima imaju znatan utjecaj, a Nijemci na samome sjeveru - u Štajerskoj i Koruškoj." ${ }^{19}$

Ponekad je ton izjava bio takav da se čak i identificiralo s težnjama Južnih Slavena ${ }^{20}$. Na vijest o nastanku Narodnoga vijeća Slovenaca, Hrvata i Srba u Krakovu je najavljena velika manifestacija slavenskoga jedinstva na koju su pozvani politički vođe iz Poljske, Češke i „Jugoslavije”. Te slavenske zemlje na jugu Europe općenito su nazivane Jugoslavijom ${ }^{21}$. Ovdje bi valjalo napomenuti da je poljsko-mađarsko prijateljstvo, koje je postojalo stoljećima, kao i opća simpatija Poljaka prema Mađarima, zahtijevalo suzdržanost u odnosu prema hrvatskim težnjama, ali mađarski su interesi u publicistici i novinskim vijestima bili čak i izostavljani, a interesi Južnih Slavena eksponirani. Poljsko javno mišljenje prihvatilo je da su važnije aspiracije Južnih Slavena od simpatija prema Mađarima, što nije imalo nikakve dublje političke dimenzije. Nitko $\mathrm{u}$ istraženim novinama nije stao u obranu mađarskoga državnog teritorija.

Općenito se o budućoj zajednici Južnih Slavena pisalo optimistički premda su savjetodavni krugovi u Poljskoj bili svjesni razlika koje su se pojavile između Hrvata i Srba. Javljalo se o kritičkom stavu hrvatskoga vođe Stjepana Radića prema projektu ujedinjenja budući da je postojala svijest o neskladu između očekivanja i državnih težnji Hrvata i Slovenaca te velikosrpskoga programa. O tome je Monitor Polski pisao 6. studenog 1918. ${ }^{22}$

I krakovski Czas u feljtonu od 10. prosinca analizirao je nesuglasje među Južnim Slavenima. Pisalo se da se među hrvatskim stanovništvom budi reakcija protiv nadmoći pravoslavlja, hrvatski vojnici koji se vraćaju s fronte bunili su se protiv ideje ujedinjenja, Stjepan Radić „morao je pobjeći u Češku zbog svoje agitacije protiv ujedinjenja sa Srbijom, Dalmatinci i Slovenci žale se da ne dobivaju odgovarajuću zaštitu pred talijanskom invazijom". Novine postavljaju izravno pitanje: „Hoće li izbiti građanski rat u Jugoslaviji?”23 Istoga je mjeseca Czas izvještavao o procesu likvidacije nezavisnosti Crne Gore. Narativ toga dnevnika bio je odraz srpskoga stava u odnosu na uzroke propasti crnogorske monarhije, osobnoga poraza kralja Nikole I., kao i prestanka državne nezavisnosti Crne Gore i njezina pripajanja Srbiji ${ }^{24}$.

19 „Ludność państwa południowo-słowiańskiego”, Monitor Polski, br. 198, 8. 11. 1918. Ovdje se očito mislilo na nekoliko gradova na jadranskoj obali, primjerice Zadar.

20 „Państwo południowo-słowiańskie”, Kurier Warszawski, br. 299, 29. 10. 1918.

21 „Manifestacja jedności słowiańskiej w Krakowie”, Ilustrowany Kurier Codzienny, br. 194, 18. 10. 1918.

22 „Rada Narodowa Słoweńców, Chorwatów i Serbów”, Monitor Polski, br. 196, 6. 11. 1918.

23 „Wojna domowa w Jugosławii?”, Czas, br. 529, 10. 12. 1918.

24 „Wielka Serbia”, Czas, br. 541, 22. 12. 1918. 
Konstituiranje Kraljevstva SHS donijelo je stanovite komentare 1919. godine. Monitor Polski u članku pod naslovom "Jugoslavija postupa solidarno” razmatra depešu Poljske telegrafske agencije iz Beograda. Komentar je bio pun zadovoljstva zbog stvaranja kraljevstva Južnih Slavena i pun nade vezano uz njegovu perspektivu. U komentaru ipak dominira srpska optika, a njegov je ton uzvišen, optimističan. Da bi se razumio smisao te izjave, treba citirati duži fragment „[...] cijela se Jugoslavija ujedinila da bi osigurala političku jednakost svojemu narodu, da bi obranila etničke granice, da bi sudjelovala u utemeljenju svjetskoga mira na osnovi Wilsonova načela. Srbi, Hrvati, Slovenci, budući da su jedan narod, govoreći jednim jezikom, naseljavajući susjedne oblasti, do sada su bili podijeljeni samo preko pritisaka i neprijateljskih intriga. Sada, oslobođeni od turske, bugarske i austrougarske okupacije, ujedinili su se u jednu državu. Srbija, Crna Gora, Bosna, Hercegovina, Dalmacija, Hrvatska, Slovenija predstavljaju danas apsolutno jedinstvo: jugoslavensko kraljevstvo ili Kraljevstvo Srba, Hrvata i Slovenaca. U novom kraljevstvu taj su plemeniti spoj priznale sve stranke, sve intelektualne grupe i sva udruženja. Nova vlada u Beogradu pravi je simbol te svete povezanosti Jugoslavije." 25

Ne znamo jesu li te riječi mišljenje izvjestitelja Poljske telegrafske agencije, redakcije Monitora Polskog ili izjave srpske strane poljskom izvjestitelju u Beogradu, ali Monitor ih je objavio kao mišljenje koje oslikava atmosferu koja je vladala u Kraljevstvu SHS i napisane su u duhu iskrenoga prijateljstva s Južnim Slavenima. Trebalo bi još jednom istaknuti da su se u Monitoru Polskom pojavljivali isključivo pozitivni izvještaji i komentari o ideji ujedinjenja Južnih Slavena. S priznanjem se govorilo i o kompetencijama političara koji su ušli u prvu vladu Kraljevine SHS: ministra vanjskih poslova Ante Trumbića ${ }^{26}$ ili potpredsjednika vlade Antona Korošca ${ }^{27}$.

Slično su se izjašnjavali poljski pisci i intelektualci, npr. Władysław Reymont (dobitnik Nobelove nagrade za književnost), Zenon Przesmycki (ministar kulture), Jan Lorentowicz (predsjednik poljskoga PEN-kluba 1925 . 1926.), Leopold Staff (književnik, dr. h. c. mult.), koji su 13. prosinca 1918. uputili svečano otvoreno pismo srpskim, hrvatskim, slovenskim i češkim piscima. U njemu su potvrđivali svoje simpatije prema Južnim Slavenima i radosno pozdravljali mogućnost suradnje među Slavenima za bolju budućnost: „U ovom svečanom trenutku našega zajedničkog praznika pozdravljamo vas s ljubavlju bratstva, pozdravljamo s prijateljskom nadom zajedničkoga života i zajedničkoga djelovanja, pozdravljamo vas sa željom da to blagoslovljeno sunce sretne budućnosti, koje se do sada probijalo samo blijedim i uskim zrakama kroz pukotine zida našega i vašega ropstva, osvjetljava snažnim zrakama naš i vaš život." 28

25 „Jugosławia działa solidarnie”, Monitor Polski, br. 9, 13. 1. 1919., 4.

26 „Trumbić ministrem spraw zagranicznych Jugosławii”, Dziennik Poznański, br. 283, 10.

12. 1918.; „Gabinet Południowosłowiański” [sic!], Naprzód, br. 282, 17. 12. 1918.

27 „Prezes klubu południowosłowiańskiego”, Dziennik Poznański, br. 281, 7. 12. 1918.

28 „Pisarze polscy do pisarzów czeskich, słowackich, słoweńskich, chorwackich i serbskich”, Monitor Polski, br. 228, 13. 12. 1918. 
Jedinu u to vrijeme široku analizu novonastale države donio je časopis Świat, tjedni društveno-kulturni magazin koji je izdavala poljska kulturna elita. U njemu se 1. lipnja 1919. pojavio članak pod veoma kratkim naslovom „SHS” (i autor se predstavio samo inicijalima: Bh. K.). Taj članak, kao i svi drugi spomenuti tekstovi, sadržava neobično pozitivne stavove autora o karakteru i ciljevima države Južnih Slavena. U uvodu autor objašnjava naslov: „Ta tri slova označavaju srpsko-hrvatsko-slovensku državu, znači Jugoslaviju, čijega smo nastanka i prvih dana postojanja svjedoci. Nije to nikakva Srbija raširena osvajanjem, nego skupina triju naroda koja oživotvoruje ideju koja se prije sto godina činila samo kao maštarija pjesnika lišenih osjećaja stvarnosti." ${ }^{29} \mathrm{U}$ nastavku je ubačena više nada nego tvrdnja: „Ujedinjeni narodi prianjaju na posao stvaranja države kao jednaki s jednakima i u bratskoj slozi, ne isključujući raznolikost pojedinih osobitosti." ${ }^{30}$ Autor je ukratko prikazao društvene uvjete, vjerske i ekonomske odnose u Kraljevstvu SHS i s velikim entuzijazmom pisao o harmoniji koja vlada u toj zemlji, a i u njezinoj politici, i pored velikih razlika. $U$ tim se riječima ogleda velika naklonost prema Jugoslavenima i vjera da će ta država biti uspješna. Autor je isticao da se jugoslavenski mislioci i političari trude osigurati gospodarsku neovisnost države i stvaranje, pored vjerskih i etničkih razlika, „takva moralnoga jedinstva zemlje koje bi predstavljalo nenarušivu osnovu općedržavnoga patriotizma i najjače utočište samoga postojanja države" ${ }^{31}$. Uz velike simpatije za državu Južnih Slavena, autor je dalje u tekstu upozorio na neke probleme koje može izazvati multietnički sastav društva. Pisao je da će biti lakše izgraditi snažnu ekonomiju zemlje nego jedinstvo u društvu. Teže će biti učvrstiti „civilizacijsko jedinstvo” i „slogu triju naroda u osjećanju povijesne uloge Jugoslavije. Danas ta uloga još nije jasna. Jugoslavensko novinstvo razmišlja o tom proble$\mathrm{mu}$, ali ga nije riješilo. Utvrdilo je tek principe da bi, stojeći na granici Zapada i Istoka, jugoslavenska kultura trebala ujediniti najbolje elemente rimske i bizantske civilizacije, stvarajući u stanovitom smislu njihovu sintezu"32.

O eventualnim opasnostima za budućnost Kraljevstva SHS pisao je svećenik Jan Urban, glavni urednik katoličkih novina Przegląd Powszechny. U članku o katolicizmu u Jugoslaviji razmišljao je o budućnosti te religije pod vlašću pravoslavne dinastije Karađorđević. Urban nije nastupao s ultrakatoličke pozicije nego suprotno, pokazivao je simpatiju za sve narode Kraljevstva SHS, bio je dosta širokih nazora kad se radilo o etničkim i vjerskim odnosima, ali je iskazivao neku vrstu bojazni hoće li država s toliko razlika opstati. „Danas se od tih tako različitih kulturnih i vjerskih neprijateljski nastrojenih dijelova”, pisao je Urban, „[...] stvara jedan politički organizam. Osjećaj potrebe obrane pred imperijalističkim težnjama susjeda, prije svega Italije, spaja te u mnogočemu toliko različite zemlje možda i više nego osjećaj jezične zajednice

\footnotetext{
29 Bh. K., „SHS”, Świat (Varšava), god. XIX, br. 25, 21. 6. 1919.

30 Isto.

31 Isto, 2.

32 Isto, 3.
} 
i podrijetla." ${ }^{33}$ No ton izjave isusovca Urbana u pitanju budućnosti Kraljevstva SHS izrazito je optimističan. On čak odbacuje bojazni publicirane na stranicama zapadnih novina. Kao podršku svojem stavu, Urban se poziva na izjavu katoličkih biskupa Hrvatske na konferenciji održanoj 30. studenog 1918. u kojoj oni izražavaju nadu i uvjerenje da će novonastala država „poštovati prava i slobodu katoličke vjere". Kao primjer za to navodi sklapanje konkordata između pravoslavne Kneževine Crne Gore i Svete Stolice nakon 1878., kao i konkordat s Kraljevinom Srbijom 1914., koji ipak nije stupio na snagu zbog izbijanja rata. $\mathrm{Na}$ toj osnovi, među ostalim, Urban formulira uvjerenje da je „zajedničko podrijetlo Južnih Slavena snažnije od vjerskih podjela među njima" ${ }^{34}$.

Podrška koju je poljsko javno mišljenje davalo stvaranju države Južnih Slavena proizlazila je iz opće simpatije prema Hrvatima, Srbima i Slovencima, ali i šire političke računice. Nastanak Kraljevstva SHS bio je dio novoga procesa - ujedinjavanja Slavena u samostalne državne organizme. Zapadni Slaveni, Poljaci, stvarali su neovisnu poljsku državu od tri dijela koja su prije zauzele Rusija, Austrija i Pruska (Njemačka), Česi i Slovaci stvorili su Čehoslovačku, Južni Slaveni proklamirali su Kraljevstvo SHS. Svaka od tih država bila je antiteza diktata velesila koji je trajao do 1914. godine. U tim se okolnostima davna poljska simpatija prema Italiji ili Mađarskoj povukla i pretvorila u podršku ili čak entuzijazam u vezi s idejom o ujedinjenju Južnih Slavena. Vrijedilo bi na kraju dodati da se takva atmosfera održavala u poljskom javnom mišljenju tijekom cijeloga međuraća. U prosincu 1931. u Poljsku je doputovao ministar vanjskih poslova Kraljevine Jugoslavije Vojislav Marinković. Bila je to prilika da se potpiše ugovor o kulturnoj i znanstvenoj suradnji. Ministar Marinković vrlo je srdačno primljen. Susreo se i s predsjednikom Ignacyjem Mościckim i maršalom Józefom Piłsudskim, a poljski je tisak oduševljeno pisao o uzajamnim poljsko-jugoslavenskim odnosima. Kao dokaz tih jako dobrih odnosa Marinković je odlikovan najvišim poljskim odlikovanjem - Ordenom bijeloga orla ${ }^{35}$. I smrt kralja Aleksandra u atentatu u Marseilleu u studenome 1934. snažno je odjeknula u poljskom javnom mišljenju. Glavni ton novinskih izvješća govorio je o strahovima za sudbinu prijateljske Jugoslavije ${ }^{36}$.

Jedan od znakova iskazivanja interesa za život Južnih Slavena bio je veoma popularan ciklus knjiga Jugoslavenska biblioteka (reportaže, lijepa književ-

\footnotetext{
33 URBAN, „Katolicyzm w Jugosławii”, 69-70.

34 Isto, 70.

35 GOŁDYN, „Echa prasowe wizyty ministra spraw zagranicznych Jugosławii”, 57-67.

36 „Zamordowanie króla Jugosławii i min. Barthou”, Kurier Poznański, br. 460, 10. 10. 1934.; „Jugosławia”, Kurier Poznański, br. 461, 11. 10. 1934.; „Tragedia Jugosławii”, Czas, br. 280, 11. 10. 1934.; „Tragedia w Marsylii”, Kurier Warszawski, 10. 10. 1934.; „Tragedia marsylska okryła żałobą cały świat kulturalny”, Gazeta Powszechna (Poznań), br. 234, 13. 10. 1934.; „Żałobny powrót króla-zjednoczyciela Jugosławii do Ojczyzny”, Ilustrowany Kurier Codzienny, br. 287, 16. 10. 1934. Jedne su novine pisale da je kralj Aleksandar, koji je inače dobio i najviše poljsko odlikovanje, Orden bijeloga orla, bio iskreni prijatelj poljske države. „Taj je osjećaj bio raširen diljem poljskoga društva.” „Król Jugosławii i min. Barthou zabici”, Express Poranny (Varšava), br. 281, 10. 10. 1934.
} 
nost, poezija itd.), čiji je inicijator bio Julije Benešić. Od 1930. do 1939. izdano je ukupno 13 tomova Jugoslavenske biblioteke, koja je uz ostalo obuhvaćala djela Miroslava Krleže, Petra II. Petrovića Njegoša, Andrije Čubranovića, ali i lijep tom pod naslovom Uroda Jugosławji, čija je autorica bila Halina Siennicka, generalni tajnik Poljsko-jugoslavenske lige.

\section{Tisak}

Czas (Krakov), 1918, 1934.

Dziennik Poznański (Poznań), 1918.

Express Poranny (Varšava), 1934.

Gazeta Powszechna, (Poznań), 1934.

Ilustrowany Kurier Codzienny (Krakov), 1918, 1934.

Kurier Poznański (Poznań), 1918, 1934.

Kurier Warszawski (Varšava), 1918, 1934.

Monitor Polski (Varšava), 1918-1919.

Naprzód (Krakov), 1918.

Świat (Varšava), 1919.

\section{Literatura}

BAŃDO, Adam. „Dzieje koncernu 'Ilustrowany Kurier Codzienny’ 19101939”. U: Kraków - Lwów. Książki - czasopisma - biblioteki XIX i XX wieku, sv. V, ur. Jerzy Jarowiecki, Kraków: Wydawnictwo Naukowe Wyższej Szkoły Pedagogicznej, 2001, 599-608.

DIMITRIJEVIĆ, Bojan; WAWRYSZUK, Paweł; ZAĆMIŃSKI, Andrzej, ur. W kręgu dyplomacji i polityki. W 100-lecie nawiązania stosunków dyplomatycznych między Polska Jugosławia. Bydgoszcz: Wydawnictwo Uniwersytetu Kazimierza Wielkiego, 2020.

GODLEWSKA, Regina. „Prasa warszawska w pierwszym roku I wojny światowej”. Rocznik Historii Czasopiśmiennictwa Polskiego 1 (1962): 246-268.

GOŁDYN, Piotr. „Echa prasowe wizyty ministra spraw zagranicznych Jugosławii Vojislava Marinkovicia w Polsce w 1931 r.” U: W kregu dyplomacji i polityki: w 100-lecie nawiązania stosunków dyplomatycznych między Polska i Jugosławią, ur. Bojan Dimitrijević, Paweł Wawryszuk i Andrzej Zaćmiński, Bydgoszcz: Wydawnictwo Uniwersytetu Kazimierza Wielkiego, 2020, 57-67.

JAROWIECKI, Jerzy. „Prasa w Krakowie: tradycja i współczesność (część pierwsza: do roku 1918)”. U: Kraków - Lwów. Książki-czasopisma - biblioteki XIX i XX wieku, sv. VI, 2. dio, ur. Jerzy Jarowiecki, Kraków: Wydawnictwo Naukowe Wyższej Szkoły Pedagogicznej, 2003, 5-35.

PAVLOVIĆ, Momčilo; WAWRYSZUK, Paweł; ZAĆMIŃSKI, Andrzej, red. Polska i Jugosławia w XX wieku. Polityka - społeczeństwo - kultura, Bydgoszcz: Wydawnictwo Uniwersytetu Kazimierza Wielkiego, 2018. 
PAVLOVIĆ, Momčilo; ZAĆMIŃSKI, Andrzej, ur. Polska i Jugosławia w stosunkach międzynarodowych po II wojnie światowej, Bydgoszcz: Wydawnictwo Uniwersytetu Kazimierza Wielkiego, 2014.

PAVLOVIĆ, Momčilo; ZAĆMIŃSKI, Andrzej; BONDŽIĆ, Dragomir, ur. Jugoslovensko-poljski odnosi u XX veku. Zbornik radova. Beograd: Institut za savremenu istoriju, 2015.

PAVLOVIĆ, Momčilo; ZAĆMIŃSKI, Andrzej; STAMBOLIJA, Nebojša, ur. Jugoslavija i Poljska. Odnosi u XX veku. Beograd: Institut za savremenu istoriju, 2019.

СТАНКОВИЋ, Ђорђе. Сто говора Николе Пашића. Вештина говорништва државника, књ. II. Београд: Рад, 2007.

STĘPNIAK, Władysław. „Działalność dyplomacji polskiej w Królestwie SHS w latach 1919-1922". Studia z Dziejów Rosji i Europy Srodkowo-Wschodniej XXXI (1996): 51-76.

URBAN, Jan. „Katolicyzm w Jugosławii”. Przeglad Powszechny (Krakov) 141-142 (1919), br. 421: 69-72. 


\section{SUMMARY}

\section{Public Opinion in Poland and the Establishment of the Kingdom of Serbs, Croats and Slovenes in 1918}

Public opinion in Poland was much interested in the developments concerning the South Slavs in the final phase of World War I. Poland was still partitioned at that time, so there was no Polish national press. However, Polish newspapers and periodicals published under Russian, German, and Austro-Hungarian administration, as well as those published in already independent Poland, welcomed the establishment of the Kingdom of Serbs, Croats and Slovenes as the realisation of the natural law of small nations to independence and thus cheered the efforts of the Slovenes, Croats, and Serbs to build their own state. There were more absorbing issues at the time, with Poland herself in the dramatic process of reclaiming independent statehood, and there was no involvement with the South Slavs, so the topic did not make it to the front pages. Nevertheless, public opinion in Poland was well versed in the activity of leading Slovenian, Serbian, and Croatian politicians and the Italian challenge to the negotiation of the borders of the newly-established state. It was also aware of the state's religious heterogeneity-Catholics, Orthodox Christians, and Muslims - as a potential threat to national unity. No particular side was favoured. Even before the unification of the Slovenes, Croats, and Serbs in a common state, the nations of Southeastern Europe were often referred to as Yugoslavia and the people as Yugoslavs. Occasionally, news concerning the South Slavs were printed in bold to emphasise the topic's importance to Polish editors and readers.

Key words: Poland; public opinion; newspapers; World War I; Kingdom of Serbs, Croats and Slovenes 